\title{
Being Somewhere
}

\begin{abstract}
To understand the experience of being present somewhere else, via a digital environment, we start by considering how we can experience being anywhere. We present several different philosophical and psychological perspectives on this, stressing the importance of perception. Each has something to offer and add to our understanding of digital travel. We compare four philosophical views: representationalism, relationism, enactivism and the sense-data view. Each has its strengths and weaknesses, but relationism is best placed to accommodate perceptual illusions, which is a prevalent view of the psychological nature of telepresence experiences. As suggested by enactivism and the direct perception approach, the possibilities for action in the world are important to the nature of our experience of places. This, in turn, is influenced by the characteristics of the world in which we act, through affordances.
\end{abstract}

Keywords Being-in-the-world P Perception · Enactivism · Telepresence · Transparency

I. Tjostheim and J. A. Waterworth, The Psychosocial Reality

of Digital Travel, https://doi.org/10.1007/978-3-030-91272-7_2 


\section{INTRODUCTION}

"I am conscious of the world through the medium of my body" (1962: 94-95). It is from the body that I perceive the world. Without a body, I have no place from which to perceive the world. "Where is begins with the location of the body. It locates me in a place." [....] "my existence as subjectivity is merely one with my existence as a body and with the existence of the world, and because the subject that I am, when taken concretely, is inseparable from this body and this world". Merleau-Ponty (1962: 408)

In Chapter 1 we outlined the background to the book, and the overall scope of topics to be covered. We address our theme-what is the psychosocial reality of virtual travel? - in stages, waypoints on our journey through the book. To experience any travel phenomena, a person needs to be able to feel they are present in a place. To qualify as travel implies that this place is somewhere other than the person's usual environment. To have the capacity to feel present in this other place, the person must have the prerequisites of feeling they are present somewhere satisfied.

In this chapter we examine what is known about this sense of being somewhere- the experience of presence in the world. Arguments are developed from relevant background theories of embodiment, perception, psychology and philosophy. Some of the contemporary philosophical background might be new terrain for the reader, but we feel that it is useful as a grounding to understand our overall argument about the impact of new technologies on the psychosocial realities of experience.

We start by examining philosophical and psychological aspects of perceiving a world from a first-person perspective. Normally, people assume that they perceive the world as it is. This is the layman's perspective on the world. There are exceptions, but in everyday life we normally do not question it-our ordinary conception of perception is of what we experience with our senses. What if the experience is mediated by technology? Can we then still use this common-sense view of perception? Perceptual experience of the environment is complicated, particularly if this involves continuous attention to and active engagement with one's surroundings, and where one's own activities, both physical and attentional, constitute key parts of the experience. One of the motivations for this chapter is to explore the theoretical background for understanding an experience in a virtual environment as an embodied perceptual experience.

Guided by our focus on telepresence, we review relevant theories from contemporary philosophy on the nature of perception, as well 
as discussing dual process theory. Stanovich and West (2000) labelled the two types of cognitive processes System 1 and System 2. Daniel Kahneman made the theory known to a wider audience in his book "Thinking, fast and slow" (2011). He states in his Nobel prize lecture (2002) "judgments and preferences are called 'intuitive' in everyday language if they come to mind quickly and effortlessly, like percepts". Telepresence may rely on rapid and effortless perceptual acceptance, as implied by Lombard and Ditton's (1997) definition of telepresence as "the illusion of non-mediation", along with the idea of transparency in the use of technology. We include a consideration of work by MerleauPonty on perception, and Heidegger's concepts of technology and transparency. The purpose is to draw attention to theories of relevance to the question: why can we have a telepresence experience-an experience of being there in another place-and how can we account for what it is theoretically?

\section{The Nature of Experiences, and of Experiences of Other Places}

Experience is an elusive term, often used without an explanation of what is meant. According to John Dewey (1922, 1925, 1938), experiences arise from the interaction a person has with his or her environment and is a process mediated in a cultural and social context. Experiences are situated; "In actual experience, there is never any such isolated singular object or event; an object or event is always a special part, phase, or aspect, of an environing experienced world - a situation". (Dewey, 1938: 67).

Heinemann (1941), with reference to the empiricist school founded by Philinos of Kos in Alexandria, distinguishes between three sorts of experiences. These are: “immediate experience, mediated experience (that is observation made by others before us), and analogous experience (thus in case of illness which has not been observed it may be useful to compare similar cases)". Heinemann, in his discussion, refers to J. A. H. Murray (Oxford, 1817) who distinguished between to have an experience of, to learn by experience, and to try something, a tentative experience. Regarding the first of these "( $i$ ) To have, experience of; to meet with; to feel; to suffer; to undergo. We could call this immediate experience; it covers what we immediately feel or undergo during the course of our life" (Heinemann, 1941: 570).

There is also a cognitive element to experience. Experiences result from knowledge, but experiences also include perceiving through the senses, as well as feeling, and doing. Logue (2009: 9) define perceptual experience 
as "experience associated with sense modalities (vision, hearing touch, smell and taste) in virtue of which it appears to one that one's environment is a certain way". The emphasis is on the word of. Therefore, a perceptual experience is a matter of a certain sort of relation between the subject of the experience and what the experience is of, that is the object of the experience. The term "experience" is used in many domains in a more applied manner, directly relevant to our main topic. Researchers such as Gallarza and Gil (2008) observe that "experiences" are a dominant focus of tourism and tourism research. Also, in consumer behaviour studies it is a frequently used term, as in the "experience economy" (Pine II \& Gilmore, 1998). In work on the experience economy it is regarded as being a multi-dimensional concept.

In most cases we assume that we perceive the world as it is. This is the layman's perspective on the world. There are exceptions, but in everyday life we normally do not question this-our ordinary conception of perception is what we experience with our senses. Robinson (2012: 618) writes, "It is, I think, universally agreed that, pre-philosophically, we are all naïve direct realists". What if the experience is mediated by technology? Should we then use this common-sense view on perception (Hudson, 2012)? Nöe and Thompson (2004: 17) write that perceptual experience is extraordinarily complicated, particularly if one realises that such experience involves a "temporally extended, active, and attentional encounter with the environment" where "the content of experience is brought forth or enacted by this activity".

The answer we give to this question has implications for the study of digital travel and the telepresence phenomenon. One of the motivations for this research was to explore the theoretical question of how to understand a visual experience in a digital environment (a VR or other kinds of digital media) as a perceptual experience (our emphasis).

\section{The Philosophy of Perceptual Experience}

The French philosopher René Descartes is often cited in publications on telepresence. Descartes postulated a separation, a dualism, between res extensa, (objects located outside the mind) and res cogitans (objects located within the mind). This is referred to as the Cartesian view. Res extensa is the substance of which the material world is made, while res cogitans is the substance of consciousness, the non-material, the thinking entity. According to Descartes res cogitans and res extensa interact in the brain, and are located in the centre of the brain (Velmans, 1995). Very 
often the mind-body problem is traced back to René Descartes and many leave out a reference to Galileo Galilei and his influential book the Assayer (Galilei, 1623). This is surprising, because in his book Galileo posits a separation between the external world and the mental world, what he calls secondary properties (Manzotti, 2006a). Galileo Galilei published his book 14 years before Descartes' "Discourse on the Method of Rightly Conducting the Reason, and Seeking Truth in the Sciences" (1637).

Many have struggled with the mind-body problem (Biocca, 1997). It concerns the relationship between the mind, perceptions and the senses. And why is it a problem? Let us, for a moment, describe telepresence as a conscious state. Then, to use Thomasson's argument "difficulties arise given the fact that we may have conscious states that present the world as having certain colours, tones, or smells, even when there is no external object possessing these features at all - indeed even when there is no object being perceived" (Thomasson, 2008: 198). The hard question concerns the relationship that exists between the objective reality of the world around us and the subjective reality of human experience.

The philosopher McGinn (1989) writes that we cannot resolve the mystery of the mind-body problem, the limits of our minds (to understand this) are not the limits of reality and that reality be constrained by what the human mind can conceive. The mind-body problem is not only discussed in philosophy. It is of relevance for cognitive psychology, and all fields that investigate how the mind works and perception. Therefore, the mind-body problem has relevance for how to understand the telepresence phenomenon (Biocca, 1997). This is the backdrop for the first research question: "Is the telepresence experience, a mediated experience, similar to or different from the perceptual unmediated experience in the material world?".

\section{Four Philosophical Views on the Nature of Perceptual Experiences}

One of our main aims is to better understand the telepresence phenomenon in relation to digital travel experiences. Few will disagree with the statement that a user of a virtual environment has a visual experience of what is presented in the VE. Some will argue that, with telepresence, there is only something digital in front of you and not something real. Tim Crane in his discussion about the problems of perception formulates these two questions: "(i) how should we account for what we see when we see what isn't there? And (ii) how should we account for those properties instantiated in experiences that are not properties of objects of experience?" 
(Crane, 2006: 25). Object of experience refers to what the experience is of, that is physical objects, but also events, olfactory and gustatory experiences (Logue, 2009). Tim Crane is an exponent of the representational view, which many philosophers share (Macpherson, 2014), but there are alternatives such as relationism, enactivism, naïve realism and the sense-data view, which we briefly review in this chapter.

Many telepresence researchers use the word virtual as opposite to real, but without any discussion of what they mean by real. In our view this is a weakness because it has implications, for instance, for research design. When choosing measurements or observational methods, it is important to keep in mind the differences between these theoretical and ontological views on perception, and whether or not the experience is veridical. In empirical studies, when participants answer survey-questions they have to find the questions and statement meaningful. There is not necessarily a good correspondence between how a layperson uses a term or understands the meaning of a word, and how the researcher or interviewer uses the same term. To ask a participant to explain or distinguish between what is real vs. what is virtual could be distracting or difficult to answer. On the other hand, we would like to know the participant's answer because it may indicate the level of presence that the participant experienced.

\section{The Representational View}

In contemporary philosophy there are two common views on perception. The first is the representational or content view. Others, such as Crane (2006) describe this view as intentionalism. Today this is the standard view in philosophy of perception (Egan, 2012); according to Kimble (2014: 2) "representationalism in one form or another is very influential in philosophical circles today". The other common view is relationism.

The representational view is a very popular theory of the nature of experience among philosophers (Macpherson, 2014), but very hard to understand for most readers. Still, we have decided to include the representational view because it gives the most straightforward explanation of telepresence. According to representationalism, what we experience are representations and the representations exist in the brain. For telepresence, this means that the there in being there is something purely mental.

The following observation by Moore (1903: 25) is well known and often quoted by representationalists. "When we try to introspect the sensation of blue, all we can see is the blue: the other element is as if it were diaphanous". Hence, visual experiences are transparent to their subjects. 
Some prefer the window or the sheet of glass metaphor to describe experiences. An experience is like a window; you don't look at it, but through it or, according to Michael Tye, visual experience can be characterised as sheets of glass. He writes:

Peer as hard as you like via introspection, focus your attention in any way you please, and you will only come across surfaces, volumes, films, and their apparent qualities. Visual experiences thus are transparent to their subjects. We are not introspectively aware of our visual experiences any more than we are perceptually aware of transparent sheets of glass. If we try to focus on our experiences, we 'see' right through them to the world outside. (Tye, 2007: 31)

In our view, this window or sheet of glass metaphor can be used to discuss the essence of telepresence and of survey instruments in telepresence that ask about what the visual experience is like.

Many philosophers, psychologists and cognitive scientists talk about perceptual experiences, or perceptual states in general, as representations (Nanay, 2012, 2015). According to representationalism the presentational character of an experience is determined by the representational content it carries; if that representational content concerns external objects and their features, then the presentational character of that experience will involve those objects and features (O'Sulllivan \& Shroer, 2012). Therefore, the qualitative character of our sensory experiences, that is, the apparent objects and properties of those experiences, are merely representational. They comprise or contain the content of those experiences without thereby being actually instantiated in the mind (Dretske, 1995; Lycan, 1996; Tye, 1995). Therefore, the representational content of a sensory experience is determined by what it is about; the phenomenal content is determined by what qualitative property it has.

A veridical experience involves two relations to two different sorts of entities: the relation of perceiving to the objects of experience, which are entities like objects, events and the properties of such entities; and the relation of perceptually representing a proposition (Logue, 2009). Philosophers who speak of perception and representation in this way include Burge, Byrne, Chalmers, Crane, Dretske, Harman, Hill, Peacocke, Searle, Siegel and Tye (Dyrstad, 2012).

There are different versions of representationalism. For the question of how to reason about and give explanations for the telepresence experience, the ontological perspective or stance of the author matters. Some advocates of representationalism distinguish between vehicle and content. 
Furthermore, the vehicle of representation is what does the representing while the content is what is being represented or what is supposed to be represented. Vehicle representationalism claims that phenomenal properties are properties of the vehicles of representation rather than properties of the external objects of perception.

In speaking about representations, then, we must be clear whether we are talking about content or vehicle, about what is represented or the representation itself. It makes a big difference. In the case of mental representations, the vehicle (a belief or an experience) is in the head. Content what is believed and experienced-is (typically) not. (Dretske, 2003: 68)

Furthermore, experiences and beliefs are conscious, not because you are conscious of them, but because you are conscious with them (Dretske, 1993: 281). This is also called a one-level view. Consciousness is fundamentally a matter of awareness of a world and does not require awareness of our own minds, mental states or the phenomenal character of these (Thomasson, 2008).

There is a form of representationalism that can be named indirect realism in which the basic idea is that the brain constructs representations. We perceive appearances, and, in virtue of perceiving these appearances, we perceive the worldly item corresponding to the appearances. Kriegel (2009) holds this view and writes "perception is mediated in the sense that objective... reality is perceived through, or in virtue of, the perception of something like a realm of appearances" (Kriegel, 2009: 96).

A representation both brings the mind in perceptual touch with the world and provides the basic form of representation of it, a representation that serves as "input" to belief and knowledge (Dyrstad, 2012). Perceptual states are about something and have a representational (or intentional) content. What a mental state is about is its intentional content or just its content. The content of perception is representational content, where representational content is specified by a representation's accuracy conditions. With this in mind we can ask whether things are as they appear. With telepresence, and, for instance, a VE, we have a digital representation of something that could be purely fantasy, but could also be something that is a quite accurate representation of the material world.

Finally, some have argued that illusions are not a problem for representationalism. The argument is that phenomenal states that are illusory or hallucinatory are like false beliefs.

"Illusions are a phenomenon easily described within a representational model of perception. Any time our knowledge doesn't accurately model its 
referent we say things are not as they 'seem' to us" (Allsop, 2010:199). Locatelli and Wilson (2017) write that:

(Representational) views have the benefit of unifying a diverse range of experiences, including hallucinations and illusions, with non-perceptual states such as thoughts, beliefs, desires, imaginings, recollections and intentional actions.

Telepresence, feeling present in a distant (or fictional) place, is an experience that some will argue has non-perceptual states. Representationalism is the dominate view in contemporary philosophy and is of value for researchers interested in telepresence theory, but is not often used as a basis for empirical work. However, in philosophy there are alternatives such as relationism, enactivism and the sense-data view.

\section{Relationism}

The fundamental idea behind the relational view (also referred to as the object view or the disjunctive view) is that perception makes the world itself manifest to the mind (Crane, 2006). The identity of a visual state is constituted by the physical facts it is about. As Crane puts it: "in perceptual experience I am not aware of qualities of my experience; I have the experience, and in having the experience, I become aware of the world" (Crane, 2006: 6). Perception is a direct relation of acquaintance between a subject and an object in the external world. Perceptions are psychologically unmediated in that perceptual contact with the world is achieved through a psychological state that is, in itself, perceptual. Furthermore, "the qualitative character of experience is constituted by the qualitative character of the scene perceived" (Campbell, 2002: 114). Snowdon (1980), Putnam (1994), Campbell (2002), Travis (2004), Martin (2004), Brewer (2006), among others, advocate relationism.

McDowell $(1994,2008)$ is primarily interested in the epistemology of perception. His position-a variety of relationism-is referred to as epistemological disjunctivism. There are two other versions of disjunctivism. They are J. M. Hinton's and Paul Snowdon's experiential disjunctivism, and M. G. F. Martin's phenomenal disjunctivism. (Haddock \& Macpherson, 2008). The experiential version is about the nature of experience or more precisely, about perceptual states. Martin (2013) prefers the label evidential disjunctivism. However, according to Locatteli (2016) the term phenomenological disjunctivism is most commonly used. 
Often illusions and hallucinations are commented on in discussions of these philosophical standpoints and theories. Soteriou (2010) writes that in a disjunctivist theory of perception, veridical perceptions and hallucinations differ mentally in some significant respect. This is because there are certain mental features that veridical perceptions have that hallucinations cannot have. Disjunctive views analyse visual experience properties in terms of success properties. In the bad cases, the non-veridical cases, they deny that we have the relevant success properties (Pautz, 2010). Brewer (2008: 173) seeks to accommodate illusions inside a relational framework. He argues: "there can be a 'visually relevant similarity' between a veridical and a non-veridical percept".

One difference, according to Soteriou (2010) between disjunctivist approaches, is the issue of whether veridical perception should be characterised as involving a relation to facts in the subject's environment, or whether veridical perceptions should, rather, be characterised as involving a relation to objects, events and their properties. McDowell adopts the former approach, whereas Campbell, Brewer and Martin adopt the latter. Furthermore, Martin argues that a disjunctive naïve realist view is the best error theory concerning perceptual experience and the introspection of experience (Soteriou, 2010).

The ordinary person's view of perception is naïve realism. It can also be named the common-sense view or the default view because it simply endorses the way in which experience subjectively strikes us; we intuitively take our experience to be an experience of worldly objects (Locatelli, 2016). Logue (2009) contends that naïve realism is in the vicinity of relationism. According to Logue (2011: 269): “Nä̈ve realism.... holds that veridical perceptual experiences fundamentally consist in the subject perceiving physical entities in her environment". Naïve realists argue that sensory experiences are relations to mind-independent objects (Martin, 2004) and "Perceiving is .... a matter of the conscious presentation of actual constituents of physical reality themselves" (Brewer, 2006: 172). Another version of relationism that deserves additional attention is enactivism.

\section{Enactivism}

Enactivism (or enactive realism) became known to a wider audience through the book The Embodied Mind (Varela et al., 1991). Enactivism holds that perception is the recognition of sensorimotor contingencies, a law-like connection between our actions and resultant sensory input. According to Manzotti (2011) enactivism builds upon the work of other 
scholars such as Gregory Bateson (1972), James J. Gibson (1972) and Maurice Merleau-Ponty (1962).

Enactive realism is based on two central principles (Roberts, 2012): (1) "perception consists in perceptually guided action" and (2) "cognitive structures emerge from the recurrent sensorimotor patterns that enable action to be perceptually guided" (Varela et al., 1991: 173). The enactive approach rejects the classical dichotomy between perception and action. The argument is that experiences are inseparable from the perceiver's bodily activities. According to enactivism, perception is not something that passively happens on us, but something we actively do. Furthermore, the human mind is embodied in our entire organism and embedded in the world. With reference to Merleau-Ponty, Varela, Thompsen and Rosch write "the subject is inseparable from the world, but from a world which the subject itself projects" (Varela et al., 1991: 4).

How does enactivism view perception? Roberts (2012: 239) writes:

The enactive realist approach contends...: all perceptual contact, and hence all perceptual consciousness, is critically dependent upon the possession and exercise of cognitive states and abilities. The perceptual relation, on this view, is to be analyzed as a relation of informed, skillful, and active exploration that cannot be instantiated unless the subject of experience is equipped with the right kind of bodily expertise.

The emphasis is on actions and interactions with the environment, and what happens when we act. "Experience isn't something that happens in $u s$, it is something we do" (Nöe, 2004: 216). Perception is from this perspective an active exploration of the environment and an interaction with the world. Enactivists argue that the core features of experiential properties are best explained by appeal to specific patterns of sensorimotor activity, through which complex self-organizing systems interact with aspects of their environment (Hutto, 2011). Perceptual presence is the sense we have of the perceptual accessibility via bodily movement (Bower \& Gallagher, 2016).

According to Roberts (2012: 240):

Enactive realism claims that physical entities, scenes, and events bear multiple, objectively-specifiable properties, all of which are possible objects of perception, but not all of which are available to every perceiver. Perceptual accessibility (our emphasis) is determined not simply by physiology. Visual accessibility is not dependent solely upon the constitution of the 
visual system, for example, nor by sensory input, but by what the perceiver knows, which determines what she is able to apprehend in experience.

Therefore, perceptual presence is a matter of access (Nöe, 2008) and we have access to more than what projects on the retina. Perceptual experience is an encounter made possible by our possession and exercise of understanding; it is a skilled-based access to what is there.

In support of a sensorimotor approach to perception, Kevin O'Regan (2011) argues that vision is a way of manipulating the environment, an exploratory activity, one motivated and sustained by our interest in our world. Limbeck-Lilienau (2013: 40) write:

Enactivism is not only a thesis about perceptual content, but also a thesis about the qualitative character of perceptual experience.....The enactive approach conceives perception as an activity, a form of doing or acting, sensorimotor knowledge and practical sensorimotor skills are constitutive for perception.

There has been some discussion of virtual presence by enactivists. For example, to Nöe (2004), virtual content refers to any aspects of objects which are available to perceptual experience without direct, occurrent perception (see also Keefer, 2009). He also discusses virtual presence and states, for example: "we have the impression that the world is represented in full detail in consciousness because, wherever we look, we encounter detail. All the detail is present, but it is only present virtually (our emphasis), for example, in the way that web site's content is present on your desktop". (Nöe, 2004: 49)

Telepresence concerns visual experiences. Interaction and action play a key role in this experience. In one of the earliest and most influential papers in telepresence, Steuer's (1992) Defining Virtual Reality, the author discusses the two dimensions of telepresence vividness and interactivity. To him these two dimensions constitute the representational powers of the technology.

\section{The Sense-data View}

British philosopher George Moore (1903) introduced the sense-data or sense-datum theory, which is also sometimes described as a theory of visual appearance (Snowdon, 2014). When the term sense data was introduced at the beginning of the last century it was a neutral term with regard to the objects of perception. Moore distinguished between the 
sense datum, which is given to the mind, and the sensation, which is the act or event of being aware of the datum. Furthermore, sense data are mind-dependent, non-physical objects (Price, 1932). The argument is that sense data exist whenever a person perceives anything, by any of the senses, and also whenever a person has an experience qualitatively like perceiving, such as a hallucination. Sense data have, according to Stanford Encyclopedia of Philosophy (Huemer, 2011), three defining characteristics; (1) sense data are the kind of thing we are directly aware of in perception, (2) sense data are dependent on the mind and 3) sense data have the properties that perceptually appear to us.

The sense-data theory claims that when we have a perceptual experience we are immediately aware of non-physical, mind-dependent objects called sense data, and shares a commitment to the idea that the structure of experience is relational. According to this view there is no mind-independent physical world responsible for the regularity of our perceptual experiences (Foster, 2000, 2008). But “whenever a sensible quality is present in experience, there must be an object which instantiates this quality" (Crane, 2005: 253). A sense experience is to be understood as a kind of sensing, where sensing is, or at least affords, awareness of something. When one focuses on one's experience, one "sees through it" and becomes aware of a sense datum (Moore, 1903). According to Austin (1962: 2): "we never directly perceive or sense, material objects or material things, but only sense-data". Objects are private mind-dependent entities and sense data are not located in physical space. We see physical things mediated by virtue of seeing real sensory items that we take to correspond to those physical things (Gandarillas, 2011). Sense data are non-physical objects in the mind that we are aware of (Macpherson, 2014).

Sensing is, or at least affords, awareness of something. Moreover, experiences are essentially presentational (Price, 1932). The presentational character of a visual experience is determined not by the external objects/properties that are the subject matter of our perceptual beliefs but by properties of sense data (O'Sullivan \& Schroer, 2012). The sensedatum theory takes perceptual consciousness to consist in an awareness of objects, but the objects in question are not the familiar denizens of the physical world, but are instead special, non-physical objects of a markedly peculiar character (Alston, 1999). Awareness of external objects can only be indirect. Item-awareness is a thesis about the objects of experience: whenever one has a visual experience, even if it is hallucinatory, there is something of which one is visually aware (Pautz, 2007). Therefore, there is no appearance-reality distinction. 
Sense-datum theorists are indirect realists. According to indirect realism, perception is a triadic relation between perceiver, a physical object that is perceived indirectly, and some private entity that is perceived directly (Brown, 1992). Perceptual access to the external or mindindependent world is indirect, relegated to the knowledge acquired through the representational capacities of sense data (Brown, 2012). Indirect realist can say that sense data are the medium by which we perceive the mind-independent world, and no more create a "veil of perception" than the fact that we use words to talk about things creates a veil of words between us and the things we talk about (Crane, 2011). Veil of perception is the idea that all one is immediately aware of is one's perceptual experience of external objects, not the objects themselves. According to Huemer (2011) veil of perception is closely related to skepticism as it empties perception of content. He further states, in a later publication (Huemer, 2011: 1) that:

Many philosophers have rejected the notion of sense data, either because they believe that perception gives us direct awareness of physical phenomena, rather than mere mental images, or because they believe that the mental phenomena involved in perception do not have the properties that appear to us.

\section{Summary of the Four Theories}

The purpose of this review has been to introduce philosophical theories and arguments of relevance to the questions of what are and why do we have telepresence experiences.

Table 2.1 summarises key characteristics of the philosophical theories reviewed above.

On the one hand, it is important to understand that we use words, terms and concepts that come from philosophy. On the other, we might not use (or be able use) the terms in accordance with how they are used in one of these four philosophical theories. Still, in order to reflect on the question of what a telepresence experience is, it is relevant to notice that there are some major differences between these four and how they account for or explain perception, as shown in Table 2.1.

In the next subsection we discuss insights from decision-making and the distinction between a fast, intuitive system and a slower reasoning system. Many choice studies in decision science focus on how we (sometimes) automatically accept information. Insights from these studies can help us to reflect on why we can have telepresence experiences. 


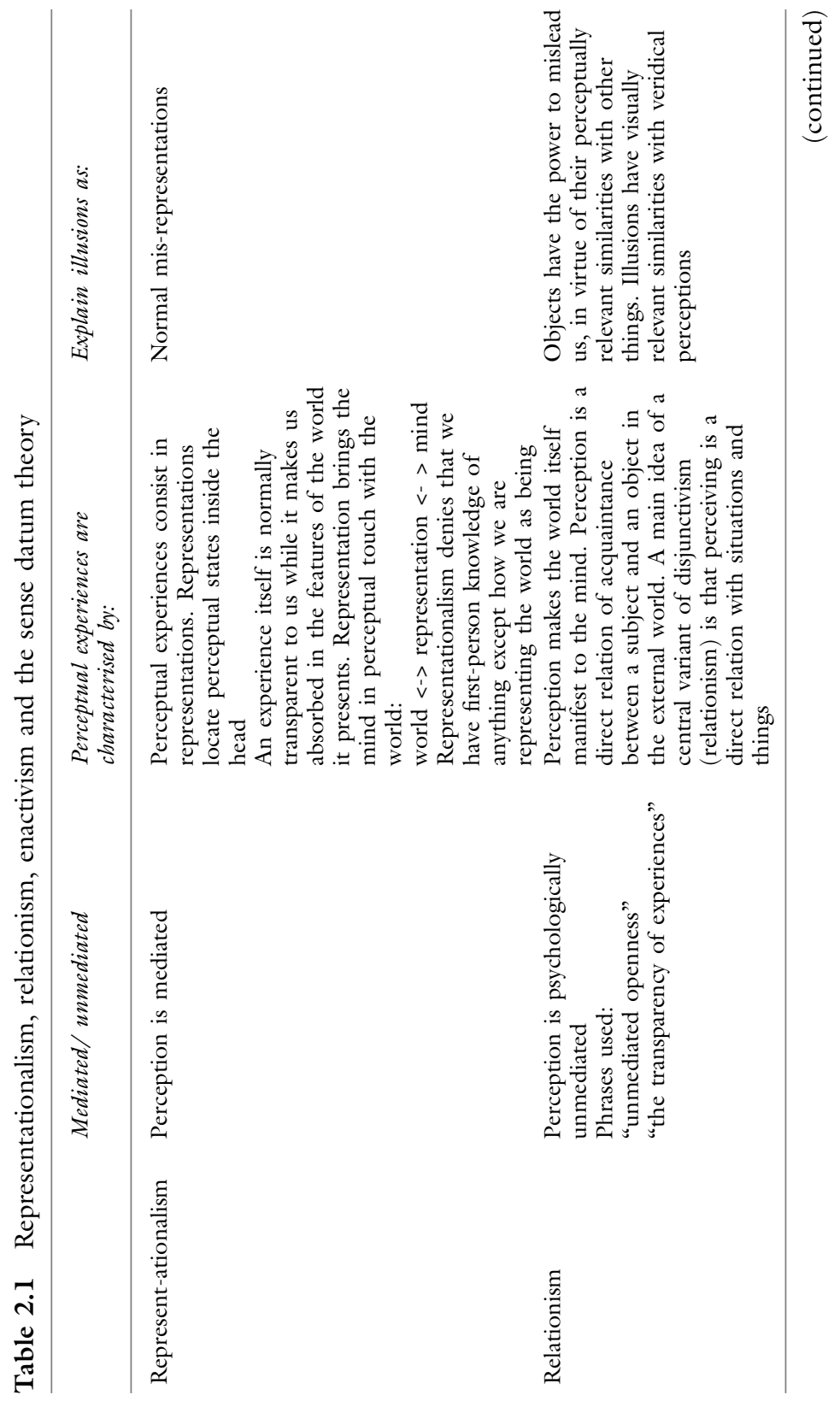




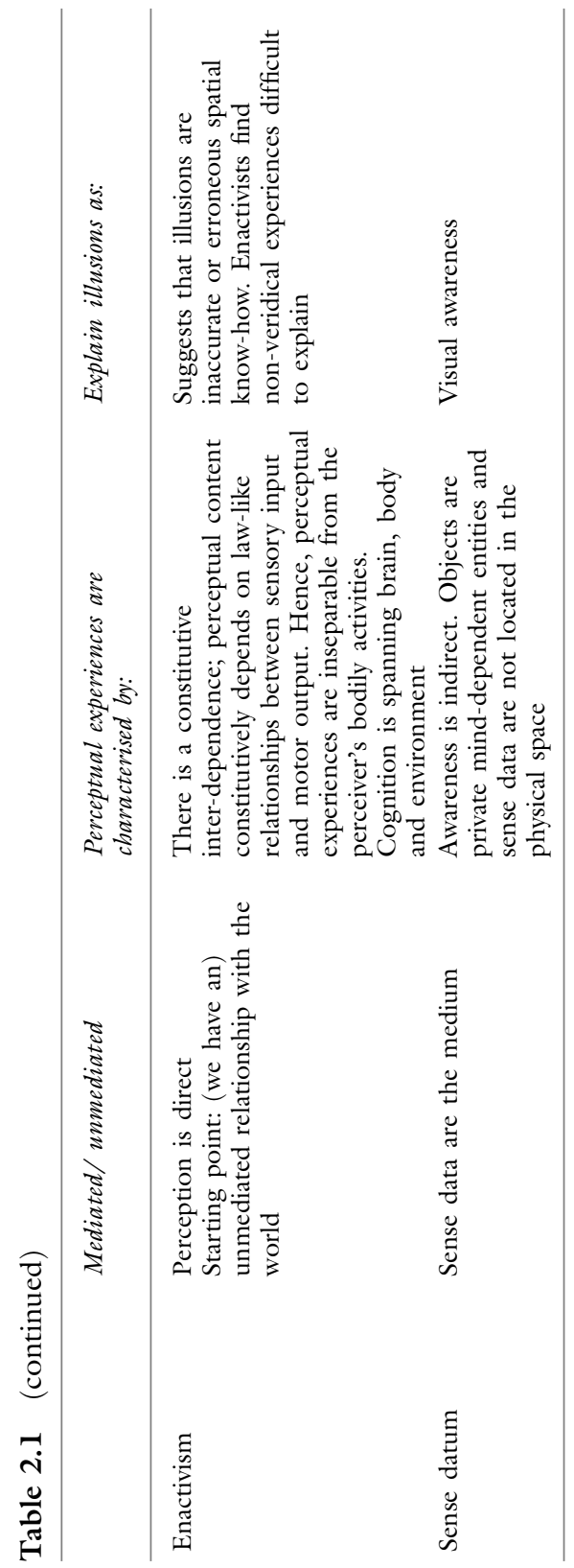




\section{Dual Process Theories and Intuitive Judgment}

Daniel Kahneman's, 2011 book, Thinking Fast and Slow, on the psychology of judgment and decision-making, is highly cited. However, the publications by Evans, Stanovich and West are even more important for the development of the dual process view. It was Stanovich (1999, Stanovich \& West, 2000) who first labelled the two types of cognitive processes system 1 and system 2 . This was based on Jonathan Evans work in the 1970s and 1980s.

System 1 is rapid, intuitive, automatic and effortless, while system 2 is slow and controlled (Kahneman, 2003). Intuitions can be described as "thoughts and preferences that come to mind quickly and without much reflection" (Kahneman, 2002). Although intuitive judgments can be viewed as an extension of perception to judgment, the distinction between perception and judgment is often blurry (Kahneman \& Frederick, 2005).

For system 1, the content level is characterised as percepts, something recognised by the senses. Kahneman and Frederick (2002) used the terms intuitive vs. reflective to characterise the two systems. In this research field, there is not an extensive discussion of illusion, but with reference to Gigerenzer (1991) Kahneman and Frederick write "there is no mystery about the conditions under which illusions appear or disappear: An intuitive judgment will be modified or overridden if System 2 identifies it as biased".

Although many researchers know about the theoretical contributions of Sloman (1996), Stanovich (1999), Kahneman and Fredericks (2002) and Kahneman $(2002,2003)$ on the two modes of thoughts, there is one question that is hard to answer that has to do with the interaction or interplay between the two systems. What is it that can explain or evoke the use of system 2, and the transition between the two systems? Can we control or choose between the two, and how does this relate to the telepresence (and the digital travel) experience?

\section{The Spinozan Model of Rapid Acceptance Response}

Dual process theory argues that in system 1 thoughts and preferences come to mind quickly and without reflection. Spinoza suggested that people believe every assertion they understand, but quickly un-believe those assertions that are found to be at odds with other established facts (Gilbert, 1989). Spinoza argued that to comprehend a proposition, a person has to implicitly accept that proposition; only later, if the person realised that this proposition conflicted with some other, might he or she change his or her mind (Gilbert, 1991). 
Richter et al. (2009) refer to the notion of an initial acceptance of information as the dual-stage model of comprehension and validation. Few have tried to test the Spinozan belief procedure. However, there are experiments that indicate that people might be able to validate and reject false information early in information processing when they have relevant background knowledge, see Trope and Gaunt (2000), Schul et al., (2004) and Richter et al. (2009).

The following quote from Gerard (1997: 332) summarises the Spinozan Model (see Fig. 2.1): “perception is quintessentially Spinozan; a percept is immediately believed. Only in the case of rare illusions are our senses tricked into believing what is not there or in to not believing what is there". It is a short step from the Spinozan belief procedure to the telepresence experience.

Type 1 processing is a common processing default (Stanovich et al., 2011). A main factor that explains this is the computational ease of system 1. When a user reports "I had a feeling of being there", that is in a place in a virtual environment, it might be this fast, automatic system 1 process that contributes to and explains why the user reports that they had the feeling of being there.

\section{The Spinozan Model}

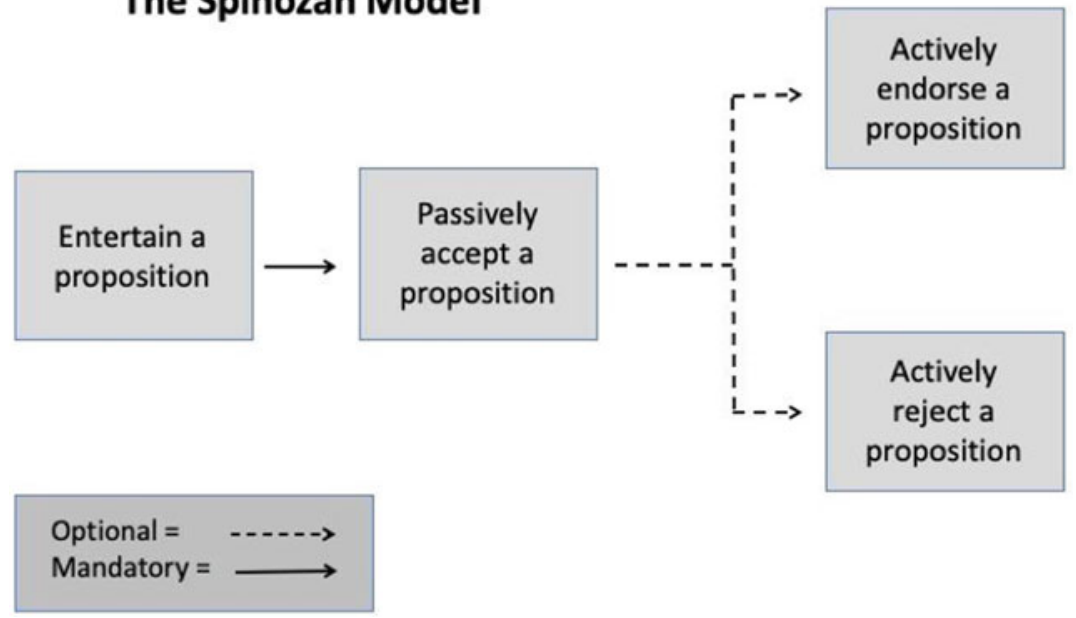

Fig. 2.1 The disposition to accept propositions-The Spinozan model 
Table 2.2 Characteristics of System 1 and System 2 thinking

\begin{tabular}{ll}
\hline System 1 & System 2 \\
\hline $\begin{array}{l}\text { Intuitive: Preconscious, automatic and } \\
\text { intimately associated with affect }\end{array}$ & $\begin{array}{l}\text { Rational: Conscious, deliberative and } \\
\text { affect-free } \\
\text { Concrete: Encodes reality in images, } \\
\text { metaphors and narratives }\end{array}$ \\
$\begin{array}{l}\text { Abstract: Encodes reality in symbols, } \\
\text { words and numbers } \\
\text { immediate action }\end{array}$ & $\begin{array}{l}\text { Slower processing: Capable of long } \\
\text { delayed action }\end{array}$ \\
Resistant to change: Changes with repetitive & $\begin{array}{l}\text { Less resistant to change: Can change } \\
\text { with speed of thought }\end{array}$ \\
or intense experience & $\begin{array}{l}\text { Experienced actively and consciously: } \\
\text { Integrated: Situationally specific; organised in believe we are in control of our }\end{array}$ \\
part by cognitive-affective modules & $\begin{array}{l}\text { thoughts } \\
\text { Not Self-evident: Requires }\end{array}$ \\
$\begin{array}{l}\text { Self-evidently valid: "Experiencing is } \\
\text { believing" }\end{array}$ & $\begin{array}{l}\text { justification via logic and evidence } \\
\text { Internally focused: Mental absence } \\
\text { fxternally focused: Mental presence in the } \\
\text { from the world }\end{array}$ \\
\hline
\end{tabular}

In discussing the psychology of presence (and telepresence), Waterworth and Riva (2014) characterised the two processes as shown in Table 2.2. According to them, presence can be characterised as the result of intuitive processing.

From judgment and decision theory we now turn to an influential philosopher of the twentieth century, Martin Heidegger. We can ask: how do we interact with and in the world, and what is the role of the body? Heidegger's philosophy of technology, his hammer metaphor and his concepts present-at-hand and ready-to-hand remain important contributions to this discourse.

\section{EVERYDAY ACTIVITIES IN THE WORLD: TRANSPARENCY AND EMBODIMENT}

To carry out activities in the world requires embodiment, and is also closely related to the sense of being and of telepresence. Normal, everyday activities need to be, and are, executed frequently and seamlessly. We use our bodies in the world without the need for conscious reflection on how we use them, or even that we are using them. This is one interpretation of the notion of transparency in embodiment, and in the use of our bodies and of the tools with which we often carry out our activities in the world. 
This notion of transparency can be extended to account for the seamless use of digital systems, and the as-if-unmediated experience of digital media.

\section{Heidegger and Modes of Engaging with the World}

Everyday activities are the starting point for Heidegger's philosophy. We have a primary and pragmatic interaction with things and the body plays a central role. To him the world is at hand in an almost literal sense. Heidegger (1927) distinguished between a tool being ready-to-hand and being present-at-hand. His famous example is the hammer which, while in use, is ready-to-hand. It is important to notice that ready-to-hand is not an object of conscious reflection. Packer (1985: 1084) summarises this in the following manner: "the kind of access of the ready-to-hand mode such as emotions, habitual practices, and skills is radically distinct from the access to phenomena provided by theoretical reflection... (The ready to hand mode) is the mode of direct practical engagement in which we actually do much of our everyday living”.

In human-computer interaction (HCI) and usability studies, many researchers cite Heidegger, probably due to this practical interpretation of technology as a tool. Figure 2.2 presents some of Heidegger's concepts with citations that explain the core meaning of the terms.

We can also see Heidegger's concepts as being on different levels of abstraction-see Fig. 2.3. The highest level is the ontological level, the level that incorporates and unifies the lower levels. It is with the concepts on the lower levels that Heidegger explains how we as humans interact, relate to and perceive the world.

Heidegger does not use the term transparency in the specific meaning related to use. For Heidegger Durchsichtigkeit has a more general scope than mere contact with technology or tools (Van Den Eede, 2011). To Heidegger circumspection, Umsicht, is the skilled possibility of concerned discovering, of concerned seeing. The term denotes the circumstances and the situation of our behaviour and how we understand the world we live in. Herstad (2007: 97) writes: "Circumspection can be interpreted as a kind of awareness which enables users to see equipment, but without asserting characteristics and properties of the equipment in use, as is the case when an object outside of a use context is seen". Herstad, therefore, suggests the term circumspective use in order to avoid an either/or visible/invisible dichotomy that too often leads to a lack of understanding of the situation 
Dasein (Being - there)

"These entities [Others] are neither present-at-hand nor ready-to-hand; on the contrary, they are like the very Dasein which frees them, in that they are there too, and there with it" (Heidegger, 1962: 154)

\section{Present at hand (Vorhandenheit)}

"The adjective "vorhanden" means literally "before the hand", but this signification has long since given way to others. In ordinary German usage it may, for instance, be applied to the stock of goods which a dealer has "on hand", or to the "extant" works of an author ..." (Heidegger, 1962: 48). "... that simple awareness of something present-at-hand in its sheer presence-athand, which Parmenides had already taken to guide him in his own interpretation of Being - has the Temporal structure of a pure "making-present" of "something" (Heidegger, 1962: 48).

Unready to hand (Unzuhandenheit) When its unusability is thus discovered, equipment becomes conspicuous. This conspicuousness presents the ready-to-hand equipment as in a certain un-readiness-to hand (Heidegger, 1962: 102-103).

"When we notice what is un-ready-to-hand, that which is ready-to-hand enters the mode of obtrusiveness" (Heidegger, 1962: 103).
Ready to hand (Zuhandenheit)

Equipment is essentially "something in-order-to. .." ['etwas um-zu. ...'] A totality of equipment is constituted by various ways of the "in-order-to", such as serviceability, conduciveness, usability, manipulability" (Heidegger, 1962: 97)

"Only because equipment has this "Being-initself" and does not merely occur, is it manipulable in the broadest sense and at our disposal" (Heidegger, 1962: 98)

Semi-transparent to transparent in use

Fig. 2.2 Heidegger and modes of engaging in the world

and context of use. The reason why Heidegger's theory has relevance for VR and telepresence primarily has to do with the transparency or semitransparency characteristic of the ready-at-hand experience.

Researchers in telepresence (e.g. Winograd, 1995; Zahorik \& Jension, 1998; etc. Benyon 2012; Sheridan 1999; Turner and Turner (2009, 2012; Turner \& Turner 2006)) refer to Heidegger's concepts, but do not discuss ready-to-hand in any detail. It is also rare to find researchers that use Heidegger's concepts in empirical studies.

In their paper Presence as Being-in-the-World, Zahorik and Jenson (1998) emphasis action as being in the centre of existence. Their thesis is that presence is tied to action in the environment. Söffner (2006: 25) gives credit to Zahorik and Jension in this passage: "Convincingly in the beginning these authors put forth a definition of presence as 'being-in-the-world'. In introducing Martin Heidegger's thoughts about 'thrownness' (Geworfenheit) and 'readiness-to-hand' (Zubandenheit) into presence theory, they allow for a distinction between presence as existence in a worldly context defined as state of acting on the one hand, and on 


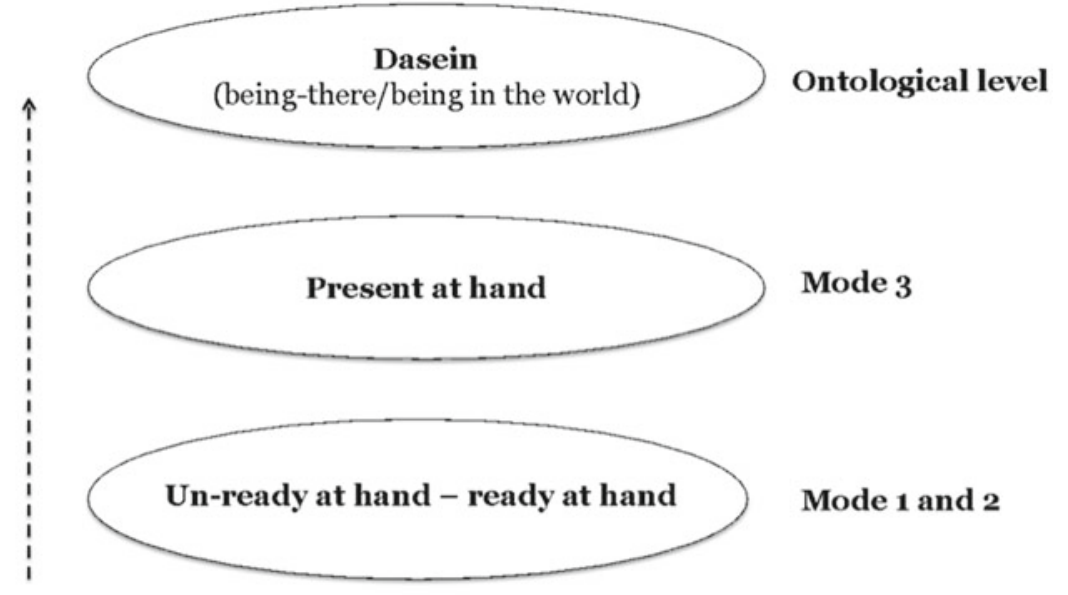

\section{Level of abstraction}

Fig. 2.3 Dasein and levels of abstraction

the other interpretation requiring stable (mental) representation that takes place necessarily outside action". Söffner advocates a view similar to Floridi who defines telepresence as an "epistemic failure".

\section{Transparency}

Surprisingly, very few authors emphasise the transparency aspect in relation to technologically mediated experiences, although there are exceptions. For instance, Riva (2009: 166) writes: "Following Heidegger, the medium is ready-to-hand". When someone has a feeling of being there, the medium is transparent. In her article The remote body, Dolezal (2009) discusses telepresence based on ideas and concepts from Husserl, Merleau-Ponty, Sartre and Gallagher. Dolezal (2009: 216) argues: "The achievement of transparency in the case of manipulating a technological object is of particular interest in the case of telepresence".

Don Ihde (2010), a philosopher of science and technology, builds on Heidegger's tool analysis when he discusses transparency. He argues that technology must be transparent enough, not wholly transparent, but "the 
closer to invisibility, transparency, and the extension of one's own bodily sense this technology allows, the better". (Ihde, 1990: 74).

We can ask: what is it that is transparent? The technology, yes, but not only the technology. Van den Eede (2011: 157) made a summary of philosophical theories discussing the transparency concept and ICT and asserts: "from a use (or designer's, or engineer's) viewpoint, awareness of the technological mediation must be as low as possible. From a context (or individual's, or reformer's, or victim's) viewpoint, consciousness of it should be as great as can possibly be accomplished. From a theorists' viewpoint, however, some form of double vision should be developed, where both sorts of transparency come in view-otherwise we risk to overlook either one or the other".

Some researchers prefer the term visible/invisible to transparency. Weiser (1991) used this as a core concept and to him, the goal is to make ICT-systems objectively visible but subjectively invisible. He states that: "A good tool is an invisible tool. By invisible, I mean that the tool does not intrude on your consciousness; you focus on the task, not the tool". (Weiser, 1994).

\section{EMBODIMENT}

We have reviewed enactivism, a theory that puts emphasis on bodily activities. It was influenced by Merleau-Ponty's work as well as Heidegger's. Merleau-Ponty does not explicitly mention Heidegger in his writings, but he has a reference to Heidegger's notion Dasein (Matthews, 2002). Merleau-Ponty places the body at the centre of his ontology, the world as we experience it. He writes: "I am conscious of the world through the medium of my body" (1962: 94-95). It is from the body that I perceive the world. Without a body, I have no place from which to perceive the world. 'Where is' begins with the location of the body. It locates me in a place". He writes: "my existence as subjectivity is merely one with my existence as a body and with the existence of the world, and because the subject that I am, when taken concretely, is inseparable from this body and this world" (Merleau-Ponty, 1962: 408). He uses the term sentir to denote a sense experience and the term coping to signify how a person is able to respond to particular situations.

By his view, the body is both the generating and the enduring aspect of experience, and an embodied consciousness (Moya, 2014). MerleauPonty (1962: 148) writes: "Our body is not primarily in space, it is of 
it and the body knows how to perceive ... it knows how to act". Human subjectivity is essentially an embodied phenomenon, and there is a circular interplay between the three; body-mind-world. For instance, we have learned from our experience how to find our way around in a city. This is "sedimented in" how that city looks to us (Dreyfus, 2007: 10). MerleauPonty calls this feedback loop between the embodied "coper" and the perceptual world, the intentional arc. He writes: "Cognitive life, the life of desire or perceptual life - is subtended by an intentional arc which projects round about us our past, our future, (and) our human setting" (Merleau-Ponty, 1962: 36). Therefore, there is a close connection and an interaction between the human body and the world. According to Fischer and Hencke (1996) Merleau-Ponty might have been influenced by Jean Piaget (1930) who described how we relate to the world as the cycle of action, assimilation and adaptation.

Merleau-Ponty's is also known for the example of the blind man's cane, concerning how we relate to the world. A blind man perceives the world through his cane. This is a skill that has to be learned and is a way of actively probing his environment. When he walks down the street, he is not primarily aware of the cane; instead he is aware of the curb. Like all other perception, it is an active communion with the world. In the context of telepresence and mediated experiences, the screen or the gameconsole is the cane. The device becomes part of the here-body experience (Ihde, 2002). Likewise, Merleau-Ponty (1962) argues that tools function as an extension of the body. To Merleau-Ponty the body itself is the perceiving subject and "sight and movement are specific ways of entering into relationship with objects" (Merleau-Ponty, 1962: 37). Commenting on this statement, Svanaes (2000: 103) writes: "any theory that locates visual perception in the eyes alone does not do justice to the phenomenon, and that it is meaningless to talk about the perceptual process of seeing without reference to all the senses".

To Merleau-Ponty (1962) the most immediate and essential aspects of the lived dimension of space are sensory experiences. In his main work The Phenomenology of Perception he reasons as follows: "by thus remaking contact with the body and with the world we shall rediscover our self, since, perceiving as we do with our body, the body is a natural self and, as it were, the subject of perception" (Merleau-Ponty, 1962: 239). Nesheim (2011: 29) writes, after reviewing Merleau-Ponty's phenomenology: "Our bodies are equipped with an extensive set of sensors that allow us to see, smell, hear touch, taste and move in connection with our surrounding". Following from this, we consider the senses and their role further below. 
Merleau-Ponty's theory of the body is a theory of perception emphasising perceptual awareness (Talero, 2005: 20). To Merleau-Ponty (1962: 229): "the senses intercommunicate by opening on to the structure of the things". Therefore, he did not perceive qualities of other parts of perception purely in themselves, but in their integrated relation with other parts (Shores, 2012). In his later writings, Merleau-Ponty reflects on vision and touch. His thesis is that vision, touch and movement are intertwined; we see only what we look at. "What would vision be without eye movement? And how could the movement of the eyes not blur things if movement were blind? If it were only a reflex?" Merleau-Ponty (1964: 162). The idea of a touching look should be taken literally. He argues that we should give up the idea of isolating the senses. Vision is intermingled with movement. There is an intrinsic relationship between my body and things around me. Not surprisingly, Merleau-Ponty can be criticised over his views. For instance, he is not consistent in how he uses the term embodiment.

In discussing the blind man's use of a cane (Merleau-Ponty, 1962: 139), he writes that the cane becomes "incorporated" into the man's body image (p. 141), but he also writes that the cane becomes " a bodily auxiliary, an extension of the bodily synthesis" (p. 153). Although embodiment is emphasised, the body as a unique field of sensory experience is often overlooked in phenomenological investigations influenced by MerleauPonty (Leder, 1990). For a further discussion of embodiment and the blind man's cane, see De Preester (2011).

Like "experience", the term "embodiment" is not easy to define. Ziemke (2003) discusses embodiment with the aim of disentangling the different claims and notions about the concept. Although there is disagreement about the meaning (Kiverstein, 2012; Metzinger, 2006) it is a key term for the so-called enactive view (see Sect. "Presence and the Direct Perception Approach"), a view that posits that perception, cognition and action are facets of a single process. As De Vignemont (2011) commented: "Merleau-Ponty initiated a long tradition of phenomenological investigation of bodilyawareness (Henri 1965; De Preester, 2007; Gallagher, 2005; Legrand, 2006; Mishara, 2004; Thompson, 2005; Zahavi \& Parnas, 1998), as well as the recent sensorimotor theories of consciousness (O'Regan and Noë, 2001; Nöe, 2004; Hurley, 1998; Thompson, 2005)".

In phenomenology and contemporary philosophy, embodiment is a popular term (Gallagher, 2005, 2018; Metzinger, 2004, 2006). Metzinger (2004) connects the concept of presence to that of transparency, which refers to the fact that our perceptions of the world and of the self appear direct, unmediated by the neurocognitive mechanisms that 
in fact give rise to them (Seth et al., 2012). Metzinger further emphasises that what is experienced is experienced now and refers to this as nowness and a temporal window of presence (Wittman, 2011).

Merleau-Ponty's ideas are highly relevant to understanding the phenomena of telepresence. Telepresence is often primarily a visual experience, but not only a visual experience. Other senses need to be invoked and engaged in a virtual environment for a strong sense of being there (presence in a digital environment) to be achieved. In the next subsection we discuss work relevant to the question of whether or not our perceptual experiences exist in the brain or outside it, with particular reference to the experience of telepresence.

\section{Presence and the Direct Perception Approach}

Loomis asserts that presence is a basic state of consciousness consisting of the attribution of sensation to some distal stimulus or environment. In the inaugural issue of the Presence: Teleoperators and Virtual Environments he writes that a simulated environment can "be so compelling as to force a user to question the assumptions that the physical and perceptual world are one and the same" (Loomis, 1992: 113). Biocca (2001) suggests, based on a philosophical grounding of a theory of presence, that presence is a sub-problem of the science of consciousness, specifically the mind-body problem. To him VE technologies potentially alter the interaction of the senses and/or motor systems with energy arrays that represent invariants of the environment such as objects, spaces and other beings.

For Biocca, presence is motivated by the desire to transcend the body "to move beyond the limits of the body and the sensory channels" (Biocca, 1997: 13) and he calls attention to what he calls the cyborg's dilemma: the extension of the human senses through technology (Mennecke et al., 2010). According to Hillis (1999: 164); "In VEs, a quasi merger of embodied perception and externally transmitted conception happens at the level of sensation".

The psychologist Max Velmans (1998, 2009), who advocates a direct perception approach, argues that human experiences occur in the phenomenal realm. Therefore, virtual realities do not fit easily into a world as-perceived model: "that dualists and reductionists assume that experiences either have no location or extension or are located and extended" (p. 3). In VR one appears to interact with a world outside one's own body although there is no actual and corresponding there surrounding the person. 
Embodiment provides the necessary bridge between external events and brain events. Sensory and motor apparatuses allow the brain to be part of a causal network linked to the external world (Manzotti, 2006b: $75)$. According to Velmans $(1998,2009)$, the VR world appears to have $3 \mathrm{D}$ location and extension outside one's body in spite of the fact that it is entirely a phenomenal experience. Therefore, VR does not seem to be without location or extension, or to be in the brain. Perceptual processing in the brain can result in experiences that have a subjective location and extension beyond the brain (Velmans, 1998: 47). Pilotti (2011) argues in a similar manner, he writes: "it is as self-evident as anything can be that all my sensory experiences are outside the brain, in the body or in the space around me. Touch is in the body where I feel the touch. (and) our sensory experiences are identical with matter, not in the brain, but out there in the now, the space or matter aspect of space-time" (Pilotti, 2011: 129). To Merleau-Ponty (1962: 169) perception is a continuous interaction involving the subject's intentions, expectations and physical actions.

Mingers (2001), building on Merleau-Ponty, uses the term embodied cognition in his works. He argues that information is objective in the sense of being independent of the observer, but the meaning that it generates is observer-dependent. He emphasises the importance of recognising the embodied and situated nature of human cognition and action. The intransitive (ontological) dimension is the domain of the real objects of scientific knowledge; the transitive (epistemological) dimension is the domain of humanly constructed cognitive objective of science such as theories, experiments and concepts. Mingers uses the term structural coupling, a concept that originates from Maturana and Varela's $(1980,1987)$ and has some similarities with how Merleau-Ponty describes embodiment.

Velmans (2009) writes that in everyday life we take the phenomenal world to be the physical world, and we treat the objects and events we perceive as if they were the objects and events themselves. "Although we normally think of the phenomenal world surrounding our body as the 'physical world', it remains part of conscious experience rather than apart from it" (Velmans, 2008: 33).

Velman's point of view is useful since it corresponds to how individuals can experience a VE, and describe their experience when it happens or just after. When someone is sightseeing in a VE of a city that actually exists, it is a predominantly visual experience, but the place is perceived as real (Slater, 1999) or, in telepresence terminology, the person has the feeling of being there. How long a feeling of being there lasts varies, and a user of a VE may often have breaks in presence (Slater \& Steed, 2000). 


\section{SuMmary AND CONCLUSIONS}

To understand the experience a sense of being in a digital environment-telepresence (or mediated presence-we started this chapter by considering how we can experience being anywhere-our perception of being in the world. We presented different philosophical and psychological perspectives on having the experience of being somewhere, stressing the importance of perception. The motivation for this was to shed light on what possible ways of understanding the experience of being in another world was created or mediated by digital technology.

We compared four philosophical views: representationalism, relationism, enactivism and the sense-data view. Each has its strengths and weaknesses, but relationism is best placed to accommodate perceptual illusions, which is a prevalent view of the psychological nature of telepresence experiences. Enactivism is also very relevant to understanding presence, as it stresses that experiences are inseparable from the perceiver's bodily activities. Each of these approaches has something to offer and add to our understanding of digital travel.

We also introduced dual process theories of cognition and suggested that acceptance of the reality of an external world, in the moment, is largely a result of intuitive, rapid cognitive processing. We emphasised the Spinozan nature of this view, which also suggests that the initial, rapid judgment may be overridden on further reflection, as we discuss in Chapter 3.

Enactivism was heavily influenced by the works of Merleau-Ponty and Gibson, in the light of the relationship between the world, embodiment, action and perception, and how these lead into the concept of transparency in interactions with the world, and with digitally mediated environments. We stressed the importance of Merleau-Ponty's view of how we perceive the world with our bodies. Digitally or not digitally, this is a basic characteristic of human experience.

Direct perception accounts of presence are appealing in the way embodiment is seen as linking mind and body, with perception understood as happening "out there", not in the brain, both for perception of the physical world and of compellingly rendered virtual world. This a key idea for understanding how digital travel can be experienced as perceptually real.

As suggested by enactivism and the direct perception approach, the possibilities for action in the world are important to the nature of our 
experience of places. This, in turn, is influenced by the characteristics of the world in which we act, through what are known as affordances.

These topics are taken up in Chapters 4 and 5 in the context of digital travel and related experiences of place and telepresence.

A subjective experience of being there at a place experienced in the moment can be accounted for theoretically with reference to the theoretical positions reviewed in this chapter. A travel experience-whether physical or digital-will also include the memory of trip, the after-travel experience. When reflecting on a digital travel experience, we will most likely conclude that it was not actual travel. But we can still have a vivid memory of what it was like to be there, if the conditions for successful digital travel have been met.

In the light of the discussions presented in this chapter, the next chapter (Chapter 3) focuses more specifically on views of telepresence, which provide a ground for discussing the related concepts of virtual tourism, place theory and relevant areas of marketing and hedonistic consumption research.

\section{REFERENCES}

Allsop, B. (2010). Representational Qualia theory. Journal of Consciousness Exploration \& Research, 1(2), 193-212.

Alston, W. P. (1999). Back to the theory of appearing. Nous, 33(s13), 181-203. https://doi.org/10.1111/0029-4624.33.s13.9

Austin, J. L. (1962). Sense and sensibilia. Oxford University Press.

Bateson, G. (1972). Steps to an ecology of mind: Collected essays in anthropology, psychiatry, evolution, and epistemology. Ballantine Books.

Benyon, D. (2012). Presence in blended spaces. Interacting with Computers, 24(4), 219-226. https://doi.org/10.1016/j.intcom.2012.04.005

Biocca, F. (1997). The Cyborg's dilemma: Progressive embodiment in virtual environments. Journal of Computer-Mediated Communication, 3(2). https:// doi.org/10.1111/j.1083-6101.1997.tb00070.x

Biocca, F. (2001). Inserting the presence of mind into a philosophy of presence: A response to Sheridan and Mantovani and Riva. Presence: Teleoperators and Virtual Environments, 10(5), 546-556. https://doi.org/10.1162/105 474601753132722

Bower, M., \& Gallagher, S. (2016). Bodily affects as prenoetic elements in enactive perception. Phenomenology and Mind, 78-93. https://doi.org/10. 13128/PHE_MI-19591 
Brewer, B. (2006). Perception and content. European Journal of Philosophy, 14(2), 165-181. https://doi.org/10.1111/j.1468-0378.2006.00220.x

Brewer, B. (2008). How to account for illusion. In A. Haddock \& F. Macpherson (Eds.), Disjunctivism: Perception, action, knowledge (pp. 168-180). Oxford: Oxford University Press.

Brown, D. H. (2012). Losing grip on the world: From illusion to sense-data. In A. Raftopoulos \& P. Machamer (Eds.), Perception, realism and the problem of reference (pp. 68-95). Cambridge University Press. https://doi.org/10. $1017 / \mathrm{CBO} 9780511979279.004$

Brown, H. I. (1992). Direct realism, indirect realism, and epistemology. Philosophy and Phenomenological Research, 52(2), 341. https://doi.org/10.2307/ 2107939

Campbell, J. (2002). Reference and consciousness. Oxford University Press. https://doi.org/10.1093/0199243816.001.0001

Crane, T. (2005). What is the problem of perception? Synthesis Philosophica, $20(2), 237-264$.

Crane, T. (2006). Is there a perceptual relation? In S. Gendler \& J. Hawthorne (Eds.), Perceptual experience (pp. 126-146). Oxford University Press.

Crane, T. (2011). Existence and quantification reconsidered. In T. E. Tahko (Ed.), Contemporary aristotelian metaphysics (pp. 44-65). Cambridge University Press. https://doi.org/10.1017/CBO9780511732256.005

De Preester, H. (2007). The deep bodily origins of the subjective perspective: Models and their problems. Consciousness and Cognition, 16(3), 604-618. https://doi.org/10.1016/j.concog.2007.05.002

De Preester, H. (2011). Technology and the body: The (im)possibilities of reembodiment. Foundations of Science, 16(2-3), 119-137. https://doi.org/10. 1007/s10699-010-9188-5

De Vignemont, F. (2011). Bodily awareness: The Standford encyclopedia of phylosophy. In E. Zalta (Ed.), (Fall 2001 ed., Vol. 2012).

Dewey, J. (1922). Human nature and conduct. Dover Publications.

Dewey, J. (1925). Experience and nature. Dover Publications.

Dewey, J. (1938). Logic: The theory of inquiry. Holt.

Dolezal, L. (2009). The remote body: The phenomenology of telepresence and reembodiment. Human Technology: An Interdisciplinary Journal on Humans in ICT Environments, 5(2), 208-226. https://doi.org/10.17011/ht/urn. 200911234471

Dretske, F. (1993). Conscious experience. Mind, 102(406), 263-283.

Dretske, F. (1995). Naturalizing the mind. MIT Press/Bradford Books.

Dretske, F. (2003). Experience as representations. Philosophical. Issues, 13(September), 67-82. 
Dreyfus, H. L. (2007). Why Heideggerian AI failed and how fixing it would require making it more Heideggerian. Artificial Intelligence, 171(18), 11371160. https://doi.org/10.1016/j.artint.2007.10.012

Dyrstad, J. (2012). Presence to mind: Representation and perceptual awareness (Master thesis), Oslo.

Egan, F. (2012). Representationalism. In E. Margolis, R. Samuels \& S. Stich (Eds.), The Oxford handbook of philosophy and cognitive science. Oxford University Press.

Fischer, K. W., \& Hencke, R. W. (1996). Infants' construction of actions in context: Piaget's contribution to research on early development. Psychological Science, 7(4), 204-210. https://doi.org/10.1111/j.1467-9280.1996. tb00360.x

Foster, J. (2000). The nature of perception. Oxford University Press. https://doi. org/10.1093/0198237693.001.0001

Foster, J. (2008). A world for us. Oxford University Press. https://doi.org/10. 1093/acprof:oso/9780199297139.001.0001

Galilei, G. (1623). The Assayer. Doubleday \& Co. https://www.princeton.edu/ nos/h291/assayer.htm

Gallagher, S. (2005). How the body shapes the mind. Oxford University Press.

Gallagher, S. (2018). Embodied rationality. In G. Bronner \& F. Di Iorio (Eds.), The mystery of rationality (pp. 83-94). Springer. https://doi.org/10.1007/ 978-3-319-94028-1_7

Gallarza, M. G., \& Gil, I. (2008). The concept of value and its dimensions: A tool for analysing tourism experiences. Tourism Review, 63(3), 4-20. https:// doi.org/10.1108/16605370810901553

Gandarillas, F. P. (2011). Sense-data, introspection and the reality of appearances. Praxis Filosófica, 33(July/December), 75-105.

Gerard, H. B. (1997). Psychic reality and unconscious belief: A reconsideration. International Journal of Psychoanalysis, 78, 327-334.

Gibson, J. J. (1972). A theory of direct visual perception. In J. Royce \& W. Rozenboom (Eds.), The psychology of knowing. Gordon \& Breach.

Gigerenzer, G. (1991). From tools to theories: A heuristic of discovery in cognitive psychology. Psychological Review, 98(2), 254-267. https://doi.org/10. 1037/0033-295X.98.2.254

Gilbert, D. T. (1989). Thinking lightly about others: Automatic components of the social inference process. In J. S. Uleman \& J. A. Bargh (Eds.), Unintended thought (pp. 189-211). The Guilford Press.

Gilbert, D. T. (1991). How mental systems believe. American Psychologist, 46(2), 107-119. https://doi.org/10.1037/0003-066X.46.2.107

Haddock, A., \& Macpherson, F. (2008). Disjunctivism. Oxford University Press. https://doi.org/10.1093/acprof:oso/9780199231546.001.0001

Heidegger, M. (1927). Being and time. Harper. 
Heinemann, F. H. (1941). The analysis of 'experience'. The Philosophical Review, 50(6 November), 561-584.

Henri, M. (1965). Philosophie et Phénoménologie du corps. Paris: Presses Universitaire de France.

Herstad, J. (2007). Circumspective use of equipment: The case of bicycle messengers. Universitetet i Oslo.

Hillis, K. (1999). Digital sensations: Space, identity and embodiment in virtual reality. University of Minnesota Press.

Hudson, R. (2012). What is a state of visual perception? International Journal of Business, Humanities and Technology, 2(1 January), 130-141. https://doi. org/10.30845/ijbht

Huemer, M. (2011). Sense data. Stanford University. plato.stanford.edu.

Hurley, S. (1998). Consciousness in action. Cambridge, MA: Harvard University Press.

Hutto, D. (2011). Consciousness. In J. Garvey (Ed.), The continuum companion to philosophy of mind. Continuum International Publishing Group.

Ihde, D. (1990). Technology and the lifeworld: From garden to earth. Indiana University Press.

Ihde, D. (2002). Bodies in technologies. University of Minnesota Press.

Ihde, D. (2010). A phenomenology of technics. In C. Hanks (Ed.), Technology and values: Essential readings. Wiley-Blackwell.

Kahneman, D. (2002). Daniel Kabneman-Prize lecture. https://www.nobelp rize.org/prizes/economic-sciences/2002/kahneman/lecture/

Kahneman, D. (2003). A perspective on judgment and choice: Mapping bounded rationality. American Psychologist, 58(9), 697-720. https://doi.org/ 10.1037/0003-066X.58.9.697

Kahneman, D. (2011). Thinking, fast and slow. Farrar.

Kahneman, D., \& Frederick, S. (2002). Representativeness revisited: Attribute substitution in intuitive judgment. In T. Gilovich, D. Griffin, \& D. Kahneman (Eds.), Heuristics and biases: The psychology of intuitive judgment (pp. 49-81). Cambridge University Press. https://doi.org/10.1017/CBO978051180809 8.004

Kahneman, D., \& Frederick, S. (2005). A model of heuristic judgment. In K. Holyoak \& B. Morrison (Eds.), The Cambridge handbook of thinking and reasoning. Cambridge University Press.

Keefer, L. A. (2009). Defending Noe's enactive theory of perception. Thesis. Georgia State University. https://scholarworks.gsu.edu/philosophy_t heses $/ 52$

Kimble, K. (2014). Varieties of representationalism and their approach to sensory experience. Philosophical Papers and Review, 5(1), 1-12. https://doi.org/10. 5897/PPR12.025 
Kiverstein, J. (2012). The meaning of embodiment. Topics in Cognitive Science, 4(4), 740-758. https://doi.org/10.1111/j.1756-8765.2012.01219.x

Kriegel, U. (2009). Subjective consciousness: A self-representational theory. Oxford University Press.

Leder, D. (1990). The absent body. University of Chicago Press.

Legrand, D. (2006). The bodily self: The sensori-motor roots of pre-reflective self-consciousness. Phenomenology and the Cognitive Sciences, 5(1), 89-118. https://doi.org/10.1007/s11097-005-9015-6

Limbeck-Lilienau, C. (2013). Seeing, blindness and illusion: A defense of the content view in perception. Universitet Wien.

Locatelli, R. (2016). In Defence of phenomenal disjunctivism. An Elucidation. Phenomenology and Mind, 4, 154-161.

Locatelli, R., \& Wilson, K. A. (2017). Introduction: Perception without representation. Topoi, 36(2), 197-212. https://doi.org/10.1007/s11245-0179460-1

Logue, H. (2009). Perceptual experience: Relations and representations. Massachusetts Institute of Technology. http://hdl.handle.net/1721.1/55181

Logue, H. (2011). The skeptic and the naïve realist. Philosophical Issues, 21(1), 268-288. https://doi.org/10.1111/j.1533-6077.2011.00204.x

Lombard, M., \& Ditton, T. (1997). At the heart of it all: The concept of presence. Journal of Computer-Mediated Communication, 3(2). https://doi.org/ 10.1111/j.1083-6101.1997.tb00072.x

Loomis, J. (1992). Distal attribution and presence. Presence: Teleoperators and virtual environments. http://dl.acm.org/citation.cfm? id=128955

Lycan, W. G. (1996). Consciousness and experience. Bradford Books.

Macpherson, F. (2014). Is the sense-data theory a representationalist theory? Ratio, 27(4), 369-392. https://doi.org/10.1111/rati.12085

Manzotti, R. (2006a). An alternative view of conscious perception. Journal of Consciousness Studies, 13(6), 45-79.

Manzotti, R. (2006b). Consciousness and existence as a process. Mind and Matter, 4(1), 7-43.

Manzotti, R. (2011). Introduction in situated aesthetics: Art beyond the skin (R. Manzotti, Ed.). (pp. 1-10). Imprint Academic.

Martin, M. G. F. (2004). The limits of self-awareness. Philosophical Studies, 120(1-3), 37-89. https://doi.org/10.1023/B:PHIL.0000033751.66949.97

Martin, M. G. F. (2013). Shibboleth: Some comments on William Fish's perception, hallucination \& illusion. Philosophical Studies, 163(1), 37-48. https:// doi.org/10.1007/s11098-012-0075-5

Matthews, E. (2002). The philosophy of Merleau-Ponty (lst ed.). Acumen Publishing Limited. https://doi.org/10.1017/UPO9781844653362

Maturana, H. R., \& Varela, F. J. (1980). Autopoiesis and cognition. Reidel Publishing Company. 
Maturana, H. R., \& Varela, F. J. (1987). The tree of knowledge: The biological roots of human understanding. Shambhala.

McDowell, J. (1994). Mind and world. Philosophical Books, 38(3), 169-181. https://doi.org/10.1111/1468-0149.00066

McDowell, J. (2008). The disjunctive conception of experience as material for a transcendental argument. In A. Haddock \& F. Macpherson (Eds.), Disjunctivism: Perception, action, knowledge (pp. 376-389). Oxford University Press.

McGinn, C. (1989). Can we solve the mind-Body problem? Mind, 98(391), 349-366.

Mennecke, B. E., Triplett, J. L., Hassall, L. M., \& Conde, Z. J. (2010). Embodied Social presence theory. 2010 43rd Hawaii International Conference on System Sciences (pp. 1-10). https://doi.org/10.1109/HICSS.2010.179

Merleau-Ponty, M. (1962). Phenomenology of perception (1962 (Paris: Gallimard, 1945)). Routledge and Kegan Paul.

Merleau-Ponty, M. (1964). Eye and mind. In The primacy of perception: And other essays on phenomenological psychology, the philosophy of art, history, and politics. Northwestern University Press.

Metzinger, T. (2004). Being no one. MIT Press.

Metzinger, T. (2006). Reply to Gallagher: Different conceptions of embodiment. PSYCHE: An Interdisciplinary Journal of Research On Consciousness, 12(4), $1-7$.

Mingers, J. (2001). Embodying information systems: The contribution of phenomenology. Information and Organization, 11(2), 103-128. https:// doi.org/10.1016/S1471-7727(00)00005-1

Mishara, A. L. (2004). The disconnection of external and internal in the conscious experience of schizophrenia: Phenomenological, literary and neuroanatomical archaeologies of self. Philosophica, 73, 87-126.

Moore, G. E. (1903). The refutation of idealism. Mind, 12(48), 433-453.

Moya, P. (2014). Habit and embodiment in Merleau-Ponty. Frontiers in Human Neuroscience, 8. https://doi.org/10.3389/fnhum.2014.00542

Nanay, B. (2012). Empirical problems with anti-representationalism. In B. Brogaard (Ed.), Does perception have content? (pp. 39-50). Oxford University Press.

Nanay, B. (2015). The representationalism versus relationism debate: Explanatory contextualism about perception. European Journal of Philosophy, 23(2), 321336.

Nesheim, E. (2011). Framing embodiment in general-purpose computing: A study identifying key components in a multimodal general-purpose computational environment [Universitet i Bergen]. https://bora.uib.no/bora-xmlui/ handle/1956/6310

Nöe, A. (2004). Action in perception. MIT Press. 
Nöe, A. (2008). Reply to Campbell Martin and Kelly. Philosophy and Phenomenological Research, 76(3), 691-706.

Nöe, A., \& Thompson, E. (2004). Are there neural correlates of consciousness? II(1), 3-28.

O'Regan, J. K. (2011). Why red doesn't sound like a bell. Oxford University Press. https://doi.org/10.1093/acprof:oso/9780199775224.001.0001

O’Regan, J. K. \& Noë, A. (2001). A sensorimotor account of vision and visual consciousness. Behavioral and Brain Sciences, 24(5), 939-973. https://doi. org/10.1017/S0140525X01000115

O'Sullivan, B., \& Schroer, R. (2012). Painful reasons: Representationalism as a theory of pain. The Philosophical Quarterly, 62(249), 737-758. https://doi. org/10.1111/j.1467-9213.2012.00092.x

Packer, M. J. (1985). Hermeneutic inquiry in the study of human conduct. American Psychologist, 40(10), 1081-1093. https://doi.org/10.1037/0003066X.40.10.1081

Pautz, A. (2007). Intentionalism and perceptual presence. Philosophical Perspectives, 21(1), 495-541. https://doi.org/10.1111/j.1520-8583.2007.00134.x

Pautz, A. (2010). Why explain visual experience in terms of content. In Perceiving the world (B. Nanay, ed.) (pp. 254-309).

Piaget, J. (1930). The Child's conception of physical causality. Harcourt.

Pilotti, J. (2011). Consciousness and physics: Towards a scientific proof that consciousness. Journal of Transpersonal Research, 3, 123-134.

Pine II, J. B., \& Gilmore, J. H. (1998, July-August). Welcome to the experience economy. Harvard Business Review.

Price, H. H. (1932). Perception. Methuen \& Co.

Putnam, H. (1994). Sense, nonsense, and the senses: An inquiry into the powers of the human mind. The Journal of Philosophy, 91(9), 445. https://doi.org/ $10.2307 / 2940978$

Richter, T., Schroeder, S., \& Wöhrmann, B. (2009). You don't have to believe everything you read: Background knowledge permits fast and efficient validation of information. Journal of Personality and Social Psychology, 96(3), 538-558. https://doi.org/10.1037/a0014038

Riva, G. (2009). Is presence a technology issue? Some insights from cognitive sciences. Virtual Reality, 13(3), 159-169. https://doi.org/10.1007/s10 055-009-0121-6

Roberts, T. (2012). Exploring enactive realism. International Journal of Philosophical Studies, 20(2), 239-254. https://doi.org/10.1080/09672559.2011. 629671

Robinson, H. (2012). Relationalism versus representationalism: How deep is the divide? The Philosophical Quarterly, 62(248), 614-619. https://doi.org/10. $1111 / j .1467-9213.2012 .00060 . x$ 
Schul, Y., Mayo, R., \& Burnstein, E. (2004). Encoding under trust and distrust: The spontaneous activation of incongruent cognitions. Journal of Personality and Social Psychology, 86(5), 668-679.

Seth, A. K., Suzuki, K., \& Critchley, H. D. (2012). An interoceptive predictive coding model of conscious presence. Frontiers in Psychology, 2. https://doi. org/10.3389/fpsyg.2011.00395

Sheridan, T. B. (1999). Descartes, Heidegger, Gibson, and god: Toward an eclectic ontology of presence. Presence: Teleoperators and Virtual Environments, 8(5), 551-559. https://doi.org/10.1162/105474699566468

Shores, C. (2012). Body and world in Merleau-Ponty and Deleuze. Studia Phaenomenologica, Romanian Society for Phenomenology, 12, 181-209. https://doi.org/10.7761/SP.12.181

Slater, M. (1999). Measuring presence: A response to the Witmer and Singer presence questionnaire. Presence: Teleoperators and Virtual Environments, 8(5), 560-565. https://doi.org/10.1162/105474699566477

Slater, M., \& Steed, A. (2000). A virtual presence counter. Presence: Teleoperators and Virtual Environments, 9(5), 413-434. https://doi.org/10.1162/ 105474600566925

Sloman, S. A. (1996). The empirical case for two systems of reasoning. Psychological Bulletin, 119(1), 3-22. https://doi.org/10.1037/0033-2909. 119.1 .3

Snowdon, P. (1980). Perception, vision and causation. Proceedings of the Aristotelian Society, New Series, 81(1980-1981), 175-192.

Snowdon, P. (2014). The philosophy of perception: An introduction. In B. Dainton \& H. Robinson (Eds.), The Bloomsbury companion to analytic philosophy (pp. 453-473). Bloomsbury Publishing.

Söffner, J. (2006). What production of presence and Mimesis have in common. Proceedings of the 9th International Workshop on Presence.

Soteriou, M. (2010). The disjunctive theory of perception. In E. Zalta (Ed.), Stanford encyclopedia of philosophy. Stanford University.

Stanovich, K. E., \& West, R. F. (2000). Individual differences in reasoning: Implications for the rationality debate? Behavioral and Brain Sciences, 23(5), 645-665. https://doi.org/10.1017/S0140525X00003435

Stanovich, K. F. (1999). Who is rational? Studies of individual differences in reasoning. Lawrence Erlbaum Associates Publishers.

Stanovich, K. E., West, R. F., \& Toplak, M. E. (2011). Individual differences in essential components of heuristics and biases research. In K. Manktelow, D. Over \& S. Elqayam (Eds.), The science of reason: A festschrift for Jonathan St BT Evans. Psychology Press.

Steuer, J. (1992). Defining virtual reality: Dimensions determining telepresence. Journal of Communication, 42(4), 73-93. https://doi.org/10.1111/j.14602466.1992.tb00812.x 
Svaneas, D. (2000). Understanding interactivity: Steps to a phenomenology of buman-computer interaction. Norges teknisk-naturvitenskapelige universitet.

Talero, M. (2005). Perception, normativity, and selfhood in Merleau-Ponty: The spatial 'level' and existential Space. The Southern Journal of Philosophy, 43(3), 443-461. https://doi.org/10.1111/j.2041-6962.2005.tb01962.x

Thomasson, A. L. (2008). Phenomenal consciousness and the phenomenal world. The Monist, 91(2), 191-214.

Thompson, E. (2005). Sensorimotor subjectivity and the enactive approach to experience. Phenomenology and the Cognitive Sciences, 4(4), 407-427. https://doi.org/10.1007/s11097-005-9003-x

Travis, C. (2004). The silence of the senses. Mind, 113(449), 57-94. https:// doi.org/10.1093/mind/113.449.57

Trope, Y., \& Gaunt, R. (2000). Processing alternative explanations of behavior: Correction or integration? Journal of Personality and Social Psychology, 79(3), 344-354. https://doi.org/10.1037/0022-3514.79.3.344

Turner, P. (2012). An everyday account of witnessing. AI \& Societty, 27(1), 5-12. https://doi.org/10.1007/s00146-011-0323-9

Turner, P., \& Turner, S. (2006). Place, sense of place, and presence. Presence: Teleoperators and Virtual Environments, 15(2), 204-217. https://doi.org/ 10.1162 /pres.2006.15.2.204

Turner, P., \& Turner, S. (2009). Triangulation in practice. Virtual Reality, 13(3), 171-181. https://doi.org/10.1007/s10055-009-0117-2

Tye, M. (1995). Ten problems of consciousness: A representational theory of the phenomenal mind. MIT Press.

Tye, M. (2007). Philosophical problems of consciousness. In M. Velmans \& S. Schneider (Eds.), The Blackwell companion to consciousness (pp. 23-35). Wiley-Blackwell.

Van Den Eede, Y. (2011). In between us: On the transparency and opacity of technological mediation. Foundations of Science, 16(2-3), 139-159. https:// doi.org/10.1007/s10699-010-9190-y

Varela, F. J., Rosch, E., \& Thompson, E. (1991). The embodied mind: Cognitive science and human experience. The MIT Press. https://doi.org/10.7551/mit press/6730.001.0001

Velmans, M. (1995). The relation of consciousness to the material world. Journal of Consciousness Studies, 2(3), 255-265.

Velmans, M. (1998). Physical, psychological and virtual realities. In John Wood (Ed.), The virtual embodied: Presence, practice, technology. Routledge.

Velmans, M. (2008). Reflexive monism. Journal of Consciousness Studies, 15(2), 5-50.

Velmans, M. (2009). Understanding consciousness. Routledge. https://doi.org/ $10.4324 / 9780203882726$ 
Waterworth, J. A., \& Riva, G. (2014). Feeling present in the physical world and in computer-mediated environments. Palgrave Macmillan.

Weiser, M. (1991). The computer for the 21st century. Scientific American, 265(3), 94-104. https://doi.org/10.1038/scientificamerican0991-94

Weiser, M. (1994). Creating the invisible interface: (Invited talk). Proceedings of the 7th Annual ACM Symposium on User Interface Software and Technology UIST '94, 1. https://doi.org/10.1145/192426.192428

Winograd, T. (1995). Heidegger and the design of computer systems. In A. Feenberg \& A. Hannay (Eds.), Technology and the politics of knowledge Indiana University Press.

Wittmann, M. (2011). Moments in time. Frontiers in Integrative Neuroscience, 5. https://doi.org/10.3389/fnint.2011.00066

Zahavi, D., \& Parnas, J. (1998). Phenomenal consciousness and self-awareness: A phenomenological critique of representational theory. Journal of Consciousness Studies, 5(5-6), 687-705.

Zahorik, P., \& Jenison, R. L. (1998). Presence as being-in-the-world. Presence: Teleoperators and Virtual Environments, 7(1), 78-89. https://doi.org/10. $1162 / 105474698565541$

Ziemke, T. (2003). What's that thing called embodiment? Avant: Trends in Interdisciplinary Studies, 6(2-3), 161-174.

Open Access This chapter is licensed under the terms of the Creative Commons Attribution 4.0 International License (http://creativecommons.org/licenses/ by $/ 4.0 /)$, which permits use, sharing, adaptation, distribution and reproduction in any medium or format, as long as you give appropriate credit to the original author(s) and the source, provide a link to the Creative Commons license and indicate if changes were made.

The images or other third party material in this chapter are included in the chapter's Creative Commons license, unless indicated otherwise in a credit line to the material. If material is not included in the chapter's Creative Commons license and your intended use is not permitted by statutory regulation or exceeds the permitted use, you will need to obtain permission directly from the copyright holder.

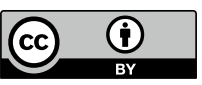

